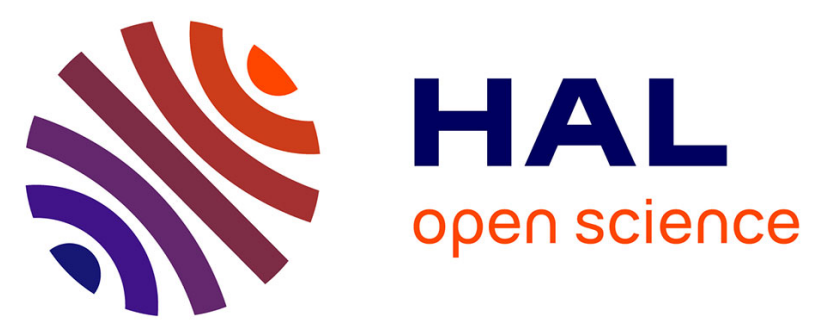

\title{
Exploring the influence of phospholipid monolayer conformation and environmental conditions on the interfacial binding of Gibberella Zeae lipase
}

Fanghua Wang, Wuchong Chen, Abdelkarim Abousalham, Bo Yang, Yonghua Wang

\section{To cite this version:}

Fanghua Wang, Wuchong Chen, Abdelkarim Abousalham, Bo Yang, Yonghua Wang. Exploring the influence of phospholipid monolayer conformation and environmental conditions on the interfacial binding of Gibberella Zeae lipase. International Journal of Biological Macromolecules, 2019, 132, pp.1051-1056. 10.1016/j.ijbiomac.2019.03.169 . hal-02132750

\section{HAL Id: hal-02132750 \\ https: / hal-udl.archives-ouvertes.fr/hal-02132750}

Submitted on 22 Jul 2019

HAL is a multi-disciplinary open access archive for the deposit and dissemination of scientific research documents, whether they are published or not. The documents may come from teaching and research institutions in France or abroad, or from public or private research centers.
L'archive ouverte pluridisciplinaire HAL, est destinée au dépôt et à la diffusion de documents scientifiques de niveau recherche, publiés ou non, émanant des établissements d'enseignement et de recherche français ou étrangers, des laboratoires publics ou privés. 


\section{Exploring the influence of phospholipid monolayer conformation and environmental conditions on the interfacial binding of Gibberella Zeae lipase}

Fanghua Wang ${ }^{\mathrm{a}}$, Wuchong Chen ${ }^{\mathrm{a}}$, Abdelkarim Abousalham ${ }^{\mathrm{b}}$, Bo Yang ${ }^{\mathrm{c}}$, Yonghua Wang ${ }^{a, *}$

${ }^{a}$ School of Food Science and Engineering, South China University of Technology, Guangzhou 510640, China

${ }^{\mathrm{b}}$ Univ Lyon, Université Lyon 1, Institut de Chimie et de Biochimie Moléculaires et Supramoléculaires (ICBMS), UMR 5246 CNRS, Métabolisme, Enzymes et Mécanismes Moléculaires $\left(\mathrm{MEM}^{2}\right)$, Bât Raulin, 43 Bd du 11 Novembre 1918, F-69622 Villeurbanne CEDEX, France

${ }^{c}$ School of Bioscience and Bioengineering, South China University of Technology, Guangzhou 510006, China

* Correspondence to Yonghua Wang: yonghw @ scut.edu.cn; Tel.: +86-20-8711-3842.

\section{Abbreviations}

GZEL, Gibberella zeae lipase; DLPC, 1,2-dilauroyl-sn-glycero-3-phosphocholine;

DMPC, 1,2-dimyristoyl-sn-glycero-3-phosphocholine; DMPE,

1,2-dimyristoyl-sn-glycero-3-phosphoethanolamine; DMPS,

1,2-dimyristoyl-sn-glycero-3-phosphoserine; DMPG,

1,2-Dimyristoyl-sn-glycero-3-phospho-(l'-rac-glycerol); $\quad$ DPPC,

1,2-dipalmitoyl-sn-glycero-3-phosphocholine; DOPC,

1,2-dioleoyl-sn-glycero-3-phosphocholine; DSPC,

1,2-distearoyl-sn-glycero-3-phosphocholine; DAPC, 
1,2-diarachidoyl-sn-glycero-3-phosphocholine; MIP, maximum insertion pressure; $\Pi_{i}$, the initial surface pressure; $\Delta \Pi$, Surface pressure increase.

\section{Highlight}

1. Phospholipid head group, chain length and unsaturation influence the adsorption of GZEL into phospholipid monolayers.

2. The $\mathrm{pH}$ and $\mathrm{NaCl}$ concentration of subphase affect the binding of GZEL to phospholipid monolayers.

3. Different $\mathrm{pH}$ can influence the secondary structure of GZEL as investigated by circular dichroism spectroscopy. 


\section{A B S T R A C T}

The involvement of different parameters on Gibberella zeae lipase (GZEL) membrane binding were characterized by using monomolecular film technology and circular dichroism spectroscopy. Among four kinds of phospholipid monolayers, 1,2-dimyristoyl-sn-glycero-3-phosphoethanolamine have the highest maximum insertion pressure (MIP) value. Comparing the GZEL adsorption to phosphatidylcholine monolayers with different acyl chains in $s n-1$ and $s n-2$ positions, the higher MIP values were found for 1,2-dilauroyl-sn-glycero-3-phosphocholine. Significantly improvement between 1,2-dioleoyl-sn-glycero-3-phosphocholine and 1,2-distearoyl-sn-glycero-3-phosphocholine suggested that the presence of fatty acid unsaturation may affect protein adsorption by changing the chemical structure in each phospholipid. The MIP value was shown higher $\left(48.6 \mathrm{mN} \mathrm{m}^{-1}\right)$ at $\mathrm{pH} 5$ and $\mathrm{pH} 6$ $\left(47.5 \pm 1.9 \mathrm{mN} \mathrm{m}^{-1}\right)$ but decreased significantly $\left(34.2 \mathrm{mN} \mathrm{m}^{-1}\right)$ at $\mathrm{pH}$ 9. This may indicate that the proportion of helices in the protein decreases with the alteration of the catalytic center, thus affecting the binding of the protein to its substrate. The MIP values obviously decreased with increasing salt ion concentration, suggesting that excessive salt ion concentration may destabilize the secondary and tertiary structures of the protein, thereby affecting the characteristics of its adsorption at the interfaces. Present studies improve our understanding on the protein-membrane interaction of this enzyme.

Keywords: Lipase, Gibberella zeae, Monolayer technology, Interfacial binding kinetics, Maximum insertion pressure 


\section{Introduction}

Biologically, the binding of proteins to membranes are involved in many biological functions, such as ion conductivity, cell adhesion, membrane trafficking and cell signaling [1,2]. The binding process can be influenced by various factors. Firstly, there is a large diversity of membrane glycerophospholipids at the polar headgroups and fatty acyl chains that are thought to modulate the binding properties of proteins to the membrane [3-6]. Secondly, some environmental factors, such as $\mathrm{pH}$ condition, presence of metal ions, or detergents on the subphase were also found to modulate the binding of proteins to the membrane [6,7]. Although a large amount of data is available on the structure of membranes, information on the selectivity of the interactions between proteins and membranes is still largely lacking [8]. The use of lipid monolayers at the air/water interface is an interesting and suitable model membrane system for studying protein-membrane interactions because it allows controlling many parameters, including both the conformation of membrane phospholipids and the environment in the subphase $[9,10]$. Moreover, there is a direct thermodynamic relationship between lipid monolayers and bilayers $[11,12]$, and it has thus been extensively used to study lipid-protein interactions. The maximum insertion pressure (MIP) and synergy factor ' $a$ ' of proteins in lipid monolayers has been shown to be useful in characterizing protein adsorption and lipid specificity without the need for radiolabels or other tags $[6,8]$.

Lipases (triacylglycerol hydrolases, E.C. 3.1.1.3) are carboxylester hydrolases that catalyze the hydrolysis of insoluble long-chain triglycerides, yielding free fatty acids, diglycerides and monoglycerides. Most lipases display regio- and enantio-selectivity during hydrolysis, alcoholysis, acidolysis and transesterification reactions and several biotechnological applications of lipases have been described in 
the detergent, cosmetic, food and pharmaceutical industries [13-15].

Lipase, like other lipolytic enzymes, is a classical interfacial acting enzyme whose catalysis is preceded by the penetration of the enzyme into the lipid /water interface [7]. Research on the interfacial binding process is a hot topic and cause much concern. Gibberella zeae Lipase (GZEL), an extracellular enzyme secreted by Fusarium oxysporum, is involved in host infection and has pathogenic effects on wheat and maize [16]. The lipolytic activity of GZEL can be inhibited in vitro and in planta by ebelactone B, a known general serine esterase inhibitor (Voigt et al. Plant Journal 2005, 42, 364-375). For this enzyme, the crystal structure has been resolved by Lou et al. [17]. GZEL was shown to be a globular protein with a catalytic triad consisting of the nucleophilic serine (S144) belonging to the usual consensus sequence GXSXG, Aspartic acid (D198) and Histidine (H257) [17], which is characteristic feature of all enzymes within the $\alpha / \beta$ hydrolase fold family $[18,19]$. As reported for many lipase structures, the GZEL catalytic site is covered by a surface loop called the lid domain located at $\alpha 3$ helix including I83 to F94 residues [17]. Although the crystallization assays of the GZEL in the open conformation were unsuccessful, a model of the enzyme complexed with a lipase inhibitor ebelactone B was proposed and allowed to predict a GZEL structure in open conformation [17]. According to this model, the transition from the closed form (inactive) to the open (active) form is accompanied by a movement of the lid domain exposing both the active site and a larger hydrophobic surface [17]. Furthermore, this lid motion could be probably the structural basis for "interfacial activation" of lipases [20-24].

In our previous research, the recombinant His-tagged GZEL has been expressed in $E$. coli (cultured by erlenmeyer flask) and the soluble enzyme has been purified to homogeneity using $\mathrm{Ni}^{2+}$-affinity resins followed by anion-exchange chromatography 
on DEAE-Sepharose column [25]. We have further characterized the substrate specificity, regio-and stereoselectivity of the recombinant GZEL using the emulsified and monomolecular film technique [25]. Moreover, functions of the C-terminal segment for the specific activity and interfacial binding properties of GZEL were also characterized in detail [26]. However, previous research mainly focuses on the enzymatic properties of the protein itself, the parameters responsible for the modulation of the membrane binding of GZEL are still largely unknown.

This study was thus performed to determine the involvement of different parameters on GZEL membrane binding. Various monolayers of phospholipids bearing different fatty acyl chain lengths $(12: 0,14: 0,16: 0,18: 0,18: 1,20: 0)$ or head groups (choline, serine, ethanolamine, glycerol) were prepared respectively by using monolayer technology to determine the influence of phospholipid conformation on protein binding. Moreover, microenvironment conditions in the subphase of water were also considered to determine the effect of different $\mathrm{pH}$ value $(4,5,6,7,8,9)$ and ion concentration $(0,0.2,0.4,0.6,0.8,1.0 \mathrm{M}$ of $\mathrm{NaCl})$ on interfacial binding of GZEL to phospholipid monolayers.

\section{Results and Discussion}

In order to study the adsorption parameters of GZEL into phospholipid monolayers, we expressed a recombinant GZEL in which the catalytic Ser144 was mutated to Ala [27]. The purified mutant was analyzed by SDS-PAGE and a single protein band with an apparent molecular mass of $60 \mathrm{KDa}$ was observed (Fig. S1).

2.1. Effect of different head group phospholipid on the binding of the GZEL to phospholipid monolayer

From our previous studies, we found that the final equilibrium surface pressure of GZEL was $24.2 \mathrm{mN} \mathrm{m}^{-1}$ and a saturation concentration for GZEL was obtained at 
$\sim 150 \mathrm{nM}$ [26]. To ensure maximum interaction between the protein and the phospholipid monolayer, a concentration of $150 \mathrm{nM}$ of purified inactive GZEL (Ser144Ala mutant) was chosen in the following experiments.

MIP correspond to the maximum insertion pressure at which proteins or peptides cannot be inserted into a single phospholipid monolayer and is widely used to characterize protein adsorption and lipid selectivity [6]. The higher the MIP value, the stronger the binding ability between protein and phospholipid monolayer. When the surface pressure exceeds this value, the intercalation of the protein into lipid monolayer cannot occur. As shown in Fig. 1A and Supplemental Fig. S2, MIPs of GZEL were found to be $36.9 \pm 1.6 \mathrm{mN} \mathrm{m}^{-1}, 47.5 \pm 1.9 \mathrm{mN} \mathrm{m}^{-1}, 45.2 \pm 1.9 \mathrm{mN} \mathrm{m}^{-1}$ and $43.1 \pm 0.9 \mathrm{mN} \mathrm{m}^{-1}$ in the presence of DMPC, DMPE, DMPG and DMPS, respectively. Among the four kinds of phospholipid monolayers, DMPE have the highest MIP value and the lowest was found for DMPC. Statistical analysis indicates that there was no significant change between DMPC, DMPS and DMPG ( $p>0.05)$. However, the low MIP value of GZEL toward DMPC may indicate that this enzyme has a low affinity for DMPC than other substrates. Synergy factor ' $a$ ' is another parameter used to evaluate the binding characteristics of protein to monolayer $[8,28]$. As it can be seen from Fig. 1B, the synergy factor ' $a$ ' was found to be $>0$ for GZEL toward different monolayer substrates, which indicated that there was a positive interaction between GZEL and the phospholipid monolayer. Proteins were easy to migrate from underwater phase to interface and bind to phospholipids. When the synergy factor $a$ approaches zero, there is no attraction or repulsion between the protein and the monolayer of the substrate $[6,8]$.

2.2. Effect of different acyl chain phospholipid on the binding of the GZEL to phospholipid monolayer 
Comparing the penetration of GZEL into different kind of PCs with same acyl chain in $s n-1$ and $s n-2$ positions can help to evaluate the effect of acyl chain length in $s n-1$ and $s n-2$ positions on protein adsorption. As can be seen from Fig. 2A and Supplemental Fig. S3, the higher MIP values were found for DLPC $\left(43.7 \pm 1.8 \mathrm{mN} \mathrm{m}^{-1}\right)$ and DOPC $\left(43.3 \pm 1.2 \mathrm{mN} \mathrm{m}^{-1}\right)$ that have acyl chains with 12 and 18 carbons, respectively, in $s n-1$ and $s n-2$ positions. While statistical analysis indicates that there are significant change in the MIP value between DLPC with other groups, there is no significant difference in the MIP value between DMPC, DPPC, DSPC and DAPC. Furthermore, the MIP value toward DOPC bearing two monounsaturated C18:1 was shown to be significantly improved $\left(43.3 \pm 1.2 \mathrm{mN} \mathrm{m}^{-1}\right)$ than the one $\left(36.1 \pm 2 \mathrm{mN} \mathrm{m}^{-1}\right)$ obtained using DSPC carrying two saturated C18:0 (Fig. 2A). These results indicate that the presence of unsaturation in the acyl chain may affect protein adsorption by changing the chemical structure in each phospholipid. It can be seen from the Fig. 2B that the synergy factor ' $a$ ' are all greater than 0 , which indicates that all of the PC tested have positive interaction toward GZEL.

\subsection{Effect of pH on the ability of GZEL binding to phospholipid monolayer}

The reaction buffer is also an environmental factor that can affect the protein adsorption properties. Various buffers that have different $\mathrm{pH}$ may have influence on the protein structure, thus affecting the protein activity. From our previous studies [25], we found that when reaction buffer $\mathrm{pH}$ was 6 , the GZEL catalytic activity was the highest and decreased in both too acid and too alkaline environments. In the present study, we used monolayer technology to further evaluate the effect of $\mathrm{pH}$ on 
protein adsorption characteristics into phospholipid monolayers. It can be found from the Figure 3A and Supplemental Fig. S4 that the maximum MIP value of GZEL (48.6 $\pm 1.7 \mathrm{mN} \mathrm{m}^{-1}$ ) occurred at $\mathrm{pH}$ 5. There is no significant difference between the MIP value obtained at $\mathrm{pH} 5$ and $\mathrm{pH} 6\left(47.5 \pm 1.9 \mathrm{mN} \mathrm{m}^{-1}\right)$. When $\mathrm{pH}$ was 4 , the MIP value of the protein decreases to $41.4 \pm 1.2 \mathrm{mN} \mathrm{m}^{-1}$ and when $\mathrm{pH}$ was 9 , the MIP value decreases to $34.2 \pm 0.9 \mathrm{mN} \mathrm{m}^{-1}$. As it can be seen from Fig. $3 \mathrm{~B}$, we found that the synergy factor ' $a$ ' was all found to be $>0$ in different $\mathrm{pH}$, which indicated that different $\mathrm{pH}$ may affect the binding properties of protein to the phospholipid monolayer but there was still a positive interaction between GZEL proteins and the phospholipid monolayer.

Circular dichroism (CD) is a useful analytical tool for probing possible conformational transitions and modifications of secondary and tertiary structures of proteins $[29,30]$. As can be seen from the results in Table 1, the main backbone conformation of GZEL at pH of 6.0 was $\alpha$-helix (28.7\%), $\beta$-sheet (20\%), turn (17.7\%) and random (35.7\%). However, the content of these structures changed when GZEL dissolved in other buffer of $\mathrm{pH}$ value (Figure 4). These results indicated that the solution of different $\mathrm{pH}$ could influence the secondary structure of protein molecules so that further influence the binding ability of GZEL to phospholipid monolayer. The main backbone conformation of GZEL at pH 9.0 was $\alpha$-helix (24.6\%), $\beta$-sheet (23\%), turn (18.5\%) and random (39.5\%) and that could partly explain why GZEL had low enzymatic activity in higher $\mathrm{pH}$ values such as 9.0 [25]. This may be due to the fact that the catalytic center of lipase is usually covered by a loop, an $\alpha$-helix or multiple 
helix structures, forming the lid domain of the majority of lipases. When the $\mathrm{pH}$ is 9 , the proportion of $\alpha$-helix decreases, and the catalytic center is modified, thus affecting the binding properties of protein to the phospholipid monolayer.

2.4. Effect of salt concentration on the ability of GZEL binding to phospholipid monolayer

Different concentrations of salt ions in the reaction solution also affect the adsorption characteristics of the protein. We chose $\mathrm{NaCl}$ that is one of the most common salt ions for research. As it can be seen from the Figure 5A and Supplemental Fig. S5, the MIP values of GZEL towards DMPE monolayers were found to be $47.5 \pm 1.9 \mathrm{mN} \mathrm{m}^{-1}$ and $49.2 \pm 1.4 \mathrm{mN} \mathrm{m}^{-1}$, using a subphase without and with $200 \mathrm{mM} \mathrm{NaCl}$, respectively. The MIP values of GZEL protein decreased obviously with the increase of salt ions concentration. It can be seen from the Fig. 5B that the synergy factor ' $a$ ' are all greater than 0 , which indicates that there was still a positive interaction between GZEL proteins and the phospholipid monolayer even in high salt ions concentration. This effect may be attributed to the fact that excessive concentration of salt ions can contribute to desorganization of the secondary and tertiary structures of the protein, thereby affecting its adsorption characteristics. The specific mechanism should be further studied.

In conclusion, present studies provide detail information on the effect of various parameters on GZEL membrane binding and improve our understanding on the protein-membrane interaction of this lipolytic enzyme. In the further work, the effects of structural changes on protein adsorption and hydrolysis properties can be further studied. 


\section{Material and methods}

\subsection{Material}

Phospholipids used in the present studies were all purchased from Larodan (Solna, Sweden): 1,2-dilauroyl-sn-glycero-3-phosphocholine

(DLPC) (>99\%),

1,2-dimyristoyl-sn-glycero-3-phosphocholine

(DMPC)

$(>99 \%)$

1,2-dimyristoyl-sn-glycero-3-phosphoethanolamine

(DMPE)

$(>99 \%)$

1,2-dimyristoyl-sn-glycero-3-phosphoserine

(DMPS)

$(>99 \%)$

1,2-dimyristoyl-sn-glycero-3-phospho-(1-rac-glycerol)

(DMPG) $\quad(>99 \%)$,

1,2-dipalmitoyl-sn-glycero-3-phosphocholine

(DPPC)

$(>99 \%)$

1,2-dioleoyl-sn-glycero-3-phosphocholine

(DOPC)

$(>99 \%)$

1,2-distearoyl-sn-glycero-3-phosphocholine

(DSPC)

$(>99 \%)$

1,2-diarachidoyl-sn-glycero-3-phosphocholine (DAPC) (>99\%) and used without further purification unless otherwise stated. Expression vectors of pFL-B62cl were from GeneCopoeia Inc. (USA). Escherichia coli SHuffle T7 Express Competent cells were purchased from New England BioLabs (Beijing, China). IPTG (isopropyl $\beta$-D-1-thiogalactopyranoside) and Ampicillin were from Sangon Biotech, Shanghai Co., Ltd. (Shanghai, China). All other reagents were of analytical grade.

\subsection{Recombinant expression and purification of inactive GZEL}

In the present study, the single Ser144Ala mutation of wild-type GZEL was used to determine the kinetic binding parameters of GZEL. The mutant was constructed and expressed as previously reported. [25,26]. Briefly, recombinant E. coli SHuffle T7 cells that harbored pFL-B62cl-GZEL-S144A plasmid were grown at $37{ }^{\circ} \mathrm{C}$ in Luria-Bertani liquid medium supplemented with $50 \mu \mathrm{g}$ mL-1 ampicillin. The seed culture was induced at an optical density of 0.8 by IPTG to a final concentration of $0.05 \mathrm{mM}$. After $24 \mathrm{~h}$ of induction at $20^{\circ} \mathrm{C}$, cells were harvested, re-suspended in 100 
$\mathrm{mL}$ of $50 \mathrm{mM}$ Tris- $\mathrm{HCl}(\mathrm{pH}$ 7.0) and disrupted by sonication. To further purify rGZEL, the supernatant was applied to a Ni2+-NTA-agarose column. The target enzyme was eluted with $50 \mathrm{mM}$ Tris- $\mathrm{HCl}$ buffer $(\mathrm{pH} 7.0$ ) containing $200 \mathrm{mM}$ imidazole. Enzyme-containing eluent was further filtered through a Sephadex G-25 column (GE Healthcare, Buckinghamshire, UK) to remove the imidazole. Samples were then loaded into a DEAE Sepharose fast flow column (GE Healthcare, Buckinghamshire, UK) and washed with $50 \mathrm{mM}$ Tris- $\mathrm{HCl}(\mathrm{pH} 7.0)$ that contain 200 $\mathrm{mM} \mathrm{NaCl}$. The fractions containing purified enzymes were collected and analyzed by 12\% SDS-PAGE. Protein concentrations were determined by the Modified Bradford Protein Assay Kit (Sangon Biotech, Shanghai Co.Ltd., Shanghai, China).

\subsection{Interfacial adsorption measurements by using monolayer technology}

GZEL protein interfacial binding measurements was performed using Microtrough from Kibron (Helsinki, Finland). The subphase $(1.2 \mathrm{~mL})$ buffer contained $50 \mathrm{mM}$ Tris- $\mathrm{HCl}(\mathrm{pH}$ 6.0) and filtered through a $0.45 \mu \mathrm{m}$ membrane was added into the Microtrough at the start of experiment. Magnetic stirrer (diameter 0.5 cm) was used at 100 r.p.m. Protein concentration must be saturated to ensure the measurement of the MIP under the maximum interaction between the protein and the phospholipid monolayer [31,32]. A few microliters of the phospholipid chloroformic solution $\left(1.0 \mathrm{mg} \mathrm{mL}^{-1}\right)$ were spread at the surface until the initial surface pressure $\left(\Pi_{\mathrm{i}}\right)$ was reached and then $50 \mu \mathrm{L}$ of the enzyme solution $\left(0.3 \mathrm{mg} \mathrm{mL}^{-1}\right)$ was injected underneath the phospholipid monolayer. The GZEL adsorption onto phospholipid monolayers was observed until equilibrium surface pressure $\left(\Pi_{e}\right)$ was reached. The surface pressure increase $(\Delta \Pi)$ is the difference between $\Pi_{\mathrm{e}}$ and $\Pi_{\mathrm{i}}[33,34]$. When $\Delta \Pi$ is graphed as function of $\Pi_{\mathrm{i}}$ the linear extrapolation of the plot to the $\mathrm{x}$-axis allows the determination of the MIP, which corresponds to the value of the surface pressure 
above which no increase occurs upon enzyme injection. The synergy factor ' $a$ ' could be deduced by adding 1 to the slope of $\Delta \Pi=f\left(\Pi_{i}\right)[33,34]$. The values of MIP, synergy factor ' $a$ ' and each value's uncertainty (calculated with a confidence interval of $95 \%$ from the covariance of the experimental data on the linear regression) were all determined by using the freely accessible web tool (http://www.crchudequebec.ulaval.ca/BindingParametersCalculator/).

\subsubsection{Effect of different head group phospholipid on the binding of the GZEL to} phospholipid monolayer

Four kinds of phospholipids with the myristoyl in both $s n-1$ and $s n-2$ positions (DMPS, DMPE, DMPC, DMPG) to determine the effect of the head group in phosphatidyl-moiety on the insertion of proteins into phospholipid monolayers. Various phospholipid solubilized in chloroform $\left(0.02 \mathrm{mg} \mathrm{mL}^{-1}\right)$ were slowly spread at the surface of a buffer (50 mM Tris- $\mathrm{HCl}, \mathrm{pH} 6.0)$ poured in one of the multi-well of the multi-well plate until the desired surface pressure was reached.

\subsubsection{Effect of different acyl chain length on the binding of the GZEL to phospholipid} monolayer

Six kinds of PC with different acyl chain in both $s n-1$ and $s n-2$ positions were chosen for present studies (DLPC, DMPC, DPPC, DSPC, DOPC, DAPC) to determine the effect of the acyl chain in phosphatidyl-moiety on the insertion of proteins into monolayers.

\subsubsection{Effect of pH of subphase buffer on the ability of GZEL binding to phospholipid} monolayer

The effect of subphase $\mathrm{pH}$ value for GZEL binding to phospholipid monolayer was determined by changing the subphase buffer with $\mathrm{pH}$ ranging from 4.0 to 9.0 which was added to multi-well plate. The buffers used in this study including $50 \mathrm{mM}$ 
citric acid-sodium citrate buffer ( $\mathrm{pH} 4.0$ and 5.0), $50 \mathrm{mM}$ Bis-Tris- $\mathrm{HCl}(\mathrm{pH} 6.0$ and 7.0), 50 mM Tris-HCl (pH 8.0), 50 mM Gly-NaOH (pH 9.0).

3.3.4. Effect of salt concentration of the subphase buffer on the ability of GZEL binding to phospholipid monolayer

Effect of salt concentration of the subphase buffer was determined by adding different amounts of $\mathrm{NaCl}$, one of the most common salt, ranging from 0 to $1.0 \mathrm{M} \mathrm{L}^{-1}$.

\subsection{Circular Dichroism Spectroscopy}

Circular dichroism measurements were carried out with a JASCO J-815 spectropolarimeter (Jasco, Tokyo, Japan) according to the method of Wang et al. (2012) [35]. The specific parameters are set as follows: scanning wavelength 180-260 nm, $0.1 \mathrm{~mm}$ colorimetric, the scanning time is $0.2 \mathrm{~nm}$ and the scanning speed is 50 $\mathrm{nm} / \mathrm{min}$. Protein samples $(0.27 \mathrm{mg} / \mathrm{ml})$ dissolved in buffers at different $\mathrm{pH}$ values (4.0, 5.0, 6.0, 9.0) were examined. An appropriate buffer solution run under the same conditions was taken as a blank and subtracted from the sample spectra. Thermal denaturation experiments were performed by monitoring the ellipticity at $222 \mathrm{~nm}$ from $25^{\circ} \mathrm{C}$ to $75^{\circ} \mathrm{C}$ and measured every $3^{\circ} \mathrm{C}$. Each simple was scanned for 3 times and each spectrum was the average of 3 scans.

\section{Acknowledgments}

This work was made possible with funding provided by the National Key R\&D Program of China (2018YFC0311100), National Natural Science Foundation of China (31671791), National Science Fund for Distinguished Young Scholars (31725022), Science and Technology Planning project of Guangdong province (2016B090920082, 2017A050503001), Talent project of scientific and technological innovation in 
Guangdong Province (2015TX01N207), Pearl River S\&T Nova Program of Guangzhou, China (201610010074).

\section{Conflict of interest}

The authors declare that they have no conflict of interest.

\section{References}

[1] W. Cho, R.V. Stahelin, Membrane-protein interactions in cell signaling and membrane trafficking, Annu Rev Biophys Biomol Struct. 34 (2005) 119-151.

[2] F.M. Goñi, Non-permanent proteins in membranes: when proteins come as visitors, Mol Membr Biol. 19 (2002) 237-245.

[3] F. Dumas, M.C. Lebrun, J.F. Tocanne, Is the protein/lipid hydrophobic matching principle relevant to membrane organization and functions? FEBS Lett. 458 (1999) 271-277.

[4] P.K. Kinnunen, A. Kõiv, J.Y. Lehtonen, M. Rytömaa, P. Mustonen, Lipid dynamics and peripheral interactions of proteins with membrane surfaces, Chem Phys Lipids 73 (1994) 181-207.

[5] É. Boisselier, P. Calvez, É. Demers, L. Cantin, C. Salesse, Influence of the physical state of phospholipid monolayers on protein binding, Langmuir 28 (2012) 9680-9688.

[6] P. Calvez, S. Bussières, D. Eric, C. Salesse, Parameters modulating the maximum insertion pressure of proteins and peptides in lipid monolayers, Biochimie 91 (2009) 718-733.

[7] A. Bénarouche, V. Point, G. Parsiegla, F. Carrière, J.F. Cavalier, New insights into the $\mathrm{pH}$-dependent interfacial adsorption of dog gastric lipase using the monolayer technique. Colloids Surf B Biointerfaces 111 (2013) 306-312.

[8] P. Calvez, E. Demers, E. Boisselier, C. Salesse, Analysis of the contribution of 
saturated and polyunsaturated phospholipid monolayers to the binding of proteins, Langmuir 27 (2011) 1373-1379.

[9] P. Dynarowicz-Latka, A. Dhanabalan, ON. Oliveira, Modern physicochemical research on Langmuir monolayers, Adv Colloid Interface Sci. 91 (2001) 221-293.

[10] G. Brezesinski, H. Mohwald, Langmuir monolayers to study interactions at model membrane surfaces, Adv. Colloid Interface Sci. 100 (2003) 563-584.

[11] F. Si-shen, Interpretation of mechanochemical properties of lipid bilayer vesicles from the equation of state or pressure-area measurement of the monolayer at the air-water or oil-water Interface, Langmuir 15 (1999) 998-1010.

[12] R.C. MacDonald, S.A. Simon, Lipid monolayer states and their relationships to bilayers, Proc. Natl. Acad. Sci. 84 (1987) 4089-4093.

[13] F. Hasan, A. A. Shah, A. Hameed, Industrial applications of microbial lipases, Enzyme Microb Technol. 39(2006) 235-251.

[14] K.E. Jaeger, T. Eggert, Lipases for biotechnology, Curr Opin Biotechnol. 13(2002) 390-397.

[15] N.S. Rios, B.B. Pinheiro, M. P. Pinheiro, R. M. Bezerra, J.C.S. dos Santos, L.R.B. Gonçalves, Biotechnological potential of lipases from Pseudomonas: sources, properties and applications. Process Biochem. 75 (2018) 99-120.

[16] C.A. Voigt, W. Schäfer, S. Salomon, A secreted lipase of Fusarium graminearum is a virulence factor required for infection of cereals, Plant J. 42 (2005) 364-375.

[17] Z. Lou, M. Li, Y. Sun, Crystal structure of a secreted lipase from Gibberella zeae reveals a novel “double-lock” mechanism, Protein \& cell. 1 (2010) 760-770.

[18] D.L. Ollis, E. Cheah, M. Cygler, B. Dijkstra, F. Frolow, S.M. Franken, M. Harel, S.J. Remington, I. Silman, J. Schrag, J.L. Sussman, K.H.G. Verschueren, A. 
Goldman, The alpha/beta hydrolase fold, Protein Eng. 5 (1992) 197-211.

[19] L. Brady, A.M. Brzozowski, Z.S. Derewenda, E. Dodson, G. Dodson, S. Tolley, J.P. Turkenburg, L. Christiansen, B. Huge-Jensen, L. Norskov, L. Thim, U. Menge, A serine protease triad forms the catalytic centre of a triacylglycerol lipase. Nature. 343 (1990) 767-770.

[20] F. Ferrato, F. Carriere, L. Sarda, R. Verger, A critical reevaluation of the phenomenon of interfacial activation, Methods Enzymol. 286 (1997) 327-347.

[21] R. Verger, Interfacial activation of lipase: facts and artifacts, Trends Biotechnol. 15 (1997) 32-38.

[22] R.D. Schmid, R. Verger, Lipases: Interfacial Enzymes with Attractive Applications, Angew Chem Int Ed Engl. 37 (1998) 1608-1633.

[23] A.M. Brzozowski, U. Derewenda, Z.S. Derewenda, G.G. Dodson, D.M. Lawson, J.P. Turkenburg, F. Bjorkling, B. Huge-Jensen, S.A. Patkar, L. Thim, A model for interfacial activation in lipases from the structure of a fungal lipase-inhibitor complex, Nature 351(1991) 491-494.

[24] K.K. Kim, H.K. Song, D.H. Shin, K.Y. Hwang, S.W. Suh, The crystal structure of a triacylglycerol lipase from Pseudomonas cepacia reveals a highly open conformation in the absence of a bound inhibitor, Structure 5 (1997) 173-185.

[25] F.H. Wang, H. Zhang, Z.X. Zhao, R.X. Wei, B. Yang, Y.H. Wang, Recombinant Lipase from Gibberella zeae Exhibits Broad Substrate Specificity: A Comparative Study on Emulsified and Monomolecular Substrate, Int J Mol Sci. 18 (2017) 1535.

[26] F.H. Wang, H. Zhang, A. Czarna, W.C. Chen, B. Yang, Y.H. Wang, Function of C-terminal peptides on enzymatic and interfacial adsorption properties of lipase from Gibberella zeae, Biochim Biophys Acta Gen Subj. 1862 (2018) 2623-2631. 
[27] M. Van Kampen, W. Simons, N. Dekker, The phospholipase activity of Staphylococcus hyicus lipase strongly depends on a single Ser to Val mutation, Chem Phys Lipids. 93 (1998) 39-45.

[28] S. Bussières, L. Cantin, B. Desbat, Binding of a truncated form of lecithin: retinol acyltransferase and its $\mathrm{N}$-and $\mathrm{C}$-terminal peptides to lipid monolayers, Langmuir 28 (2012) 3516-3523.

[29] Y.F. Shen, F.H. Wang, D.M. Lan, Y. Liu, B. Yang, Y.H. Wang, Biochemical Properties and Potential Applications of Recombinant Leucine Aminopeptidase from Bacillus kaustophilus CCRC 11223, Int J Mol Sci. 12 (2011) 7609.

[30] B.A. Wallace, J.G. Lees, A.J.W. Orry, A. Lobley, R.W. Janes, Analyses of circular dichroism spectra of membrane proteins, Protein Sci. 12 (2003) 875-884.

[31] M. Lhor, S. C. Bernier, H. Horchani, Comparison between the behavior of different hydrophobic peptides allowing membrane anchoring of protein, Adv Colloid Interface Sci. 207 (2014) 223-239.

[32] W.E. Momsen, H.L. Brockman, The adsorption to and hydrolysis of 1 , 3-didecanoyl glycerol monolayers by pancreatic lipase, Effects of substrate packing density, J Biol Chem. 256 (1981) 6913-6916.

[33] W.E. Momsen, J.M. Smaby, H. L. Brockman, Interfacial structure and lipase action. Characterization of taurodeoxycholate-didecanoylglycerol monolayers by physical and kinetic methods, J Biol Chem. 254 (1979) 8855-8860.

[34] J.P. Barque, D.G. Dervichian, Enzyme-substrate interaction in lipid monolayers. II. Binding and activity of lipase in relation to enzyme and substrate concentration and to other factors, J Lipid Res. 20 (1979) 447-455.

[35] F.H. Wang, Z.X. Ning, D.M. Lan, Y.Y. Liu, B. Yang, Y.H. Wang, Biochemical Properties of Recombinant Leucine Aminopeptidase II from Bacillus 
stearothermophilus and Potential Applications in the Hydrolysis of Chinese Anchovy (Engraulis japonicus) Proteins, J Agric Food Chem. 60 (2012) 165-172. 


\section{Figure legends:}

Figure 1. MIP (A) and Synergy factor ' $a$ ' (B) of GZEL (9.08 $\mu \mathrm{g} \mathrm{mL} \mathrm{m}^{-1}$, final concentration) obtained in the presence of different phospholipid monolayer. The buffer was $50 \mathrm{mM}$ Tris- $\mathrm{HCl}(\mathrm{pH}$ 6.0). Statistical analysis of the data allowed to determine the values which were significantly different and labeled with different characters $(\mathrm{p}=0.05)$.

Figure 2. MIP (A) and Synergy factor ' $a$ ' (B) of GZEL $\left(9.08 \mu \mathrm{g} \mathrm{mL} \mathrm{m}^{-1}\right.$, final concentration) obtained in the presence of phosphatidylcholine that have different acyl chain length. The buffer was $50 \mathrm{mM}$ Tris- $\mathrm{HCl}(\mathrm{pH}$ 6.0). Statistical analysis of the data allowed to determine the values which were significantly different and labeled with different characters $(\mathrm{p}=0.05)$.

Figure 3. MIP (A) and Synergy factor ' $a$ ' (B) of GZEL $\left(9.08 \mu \mathrm{g} \mathrm{mL} \mathrm{m}^{-1}\right.$, final concentration) interaction with 1,2-dimyristoyl-sn-glycero-3-phosphoethanolamine (DMPE) monolayers obtained in the conditions of different $\mathrm{pH}$ reaction buffer. The buffer was $50 \mathrm{mM}$ Tris-HCl $(\mathrm{pH}$ 6.0). Statistical analysis of the data allowed to determine the values which were significantly different and labeled with different characters $(\mathrm{p}=0.05)$.

Figure 4. Circular dichroism of GZEL under various $\mathrm{pH}$ buffers. GZEL (0.27 mg $\mathrm{mL}^{-1}$, final concentration) was dissolved in buffers at different $\mathrm{pH}$ values $(4.0,5.0,6.0$, 9.0) and the thermal denaturation experiments were performed by monitoring the ellipticity at $222 \mathrm{~nm}$ from $25^{\circ} \mathrm{C}$ to $75^{\circ} \mathrm{C}$ and measured every $3^{\circ} \mathrm{C}$. Each simple was scanned for 3 times and each spectrum was the average of 3 scans. 
Figure 5. Maximum insertion pressure (MIP) (A) and Synergy factor ' $a$ ' (B) of GZEL obtained in the presence of reaction buffer that containing different $\mathrm{NaCl}$ concentration. The buffer was $50 \mathrm{mM}$ Tris- $\mathrm{HCl}(\mathrm{pH}$ 6.0). Statistical analysis of the data allowed to determine the values which were significantly different and labeled with different characters $(\mathrm{p}=0.05)$. 
Table 1. Fractions of different secondary structures of GZEL that dissolved in various $\mathrm{pH}$ buffers

\begin{tabular}{lllll}
\hline & $4.0(\%)$ & $5.0(\%)$ & $6.0(\%)$ & $9.0(\%)$ \\
\hline Helix & 31.1 & 32.5 & 28.7 & 24.6 \\
Sheet & 18.4 & 17.7 & 20.0 & 23.0 \\
Turn & 17.2 & 17.0 & 17.7 & 18.5 \\
Random & 33.6 & 32.7 & 35.7 & 39.5 \\
\hline
\end{tabular}


A

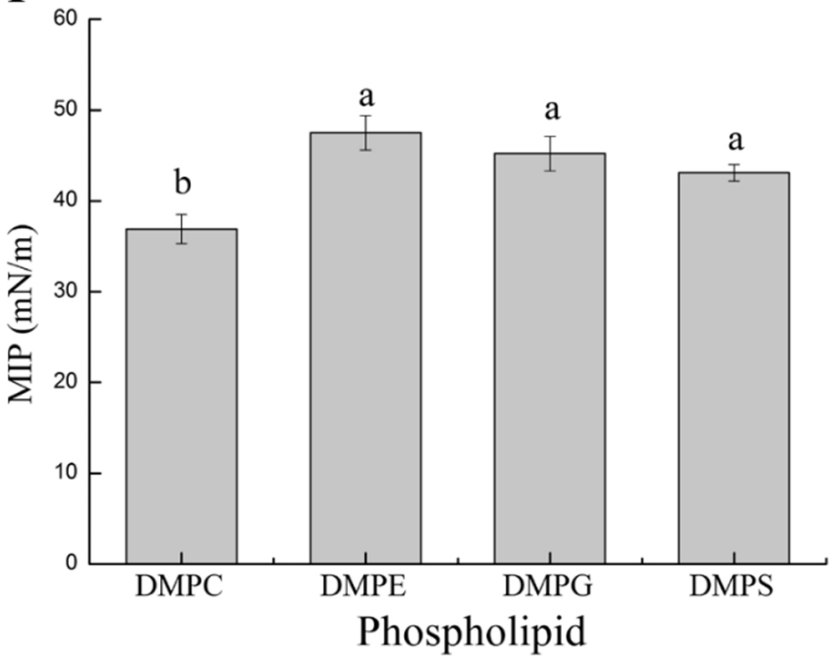

B

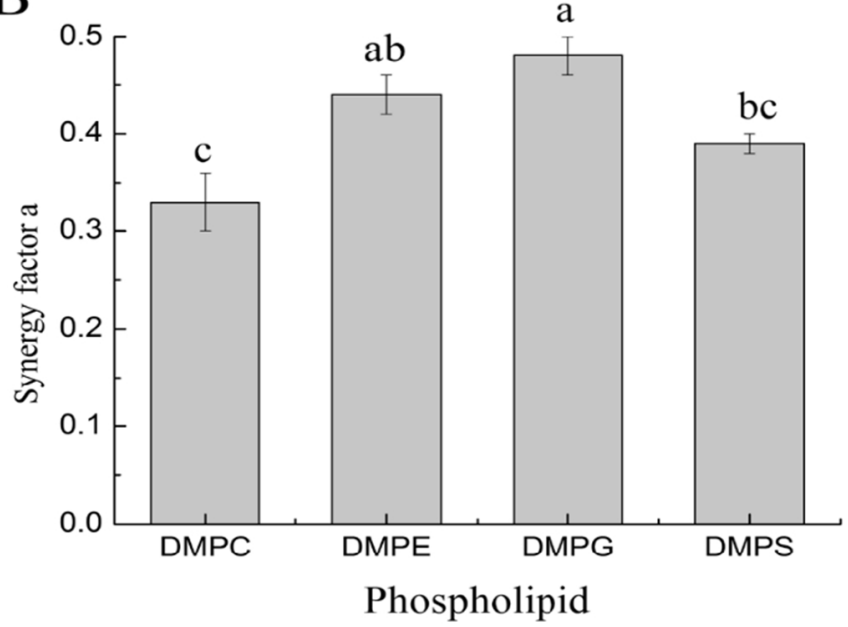

Figure 1 
A ${ }^{50}[\mathrm{a}$

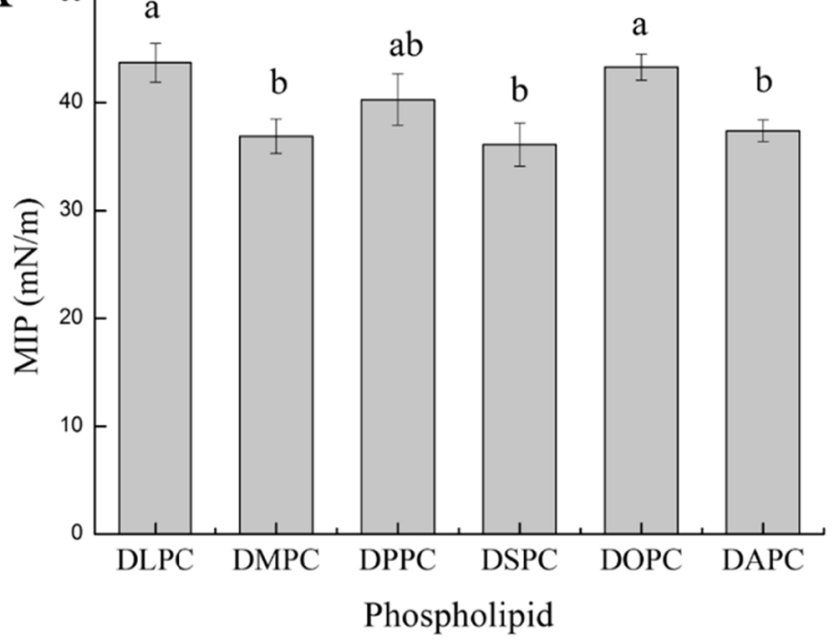

B

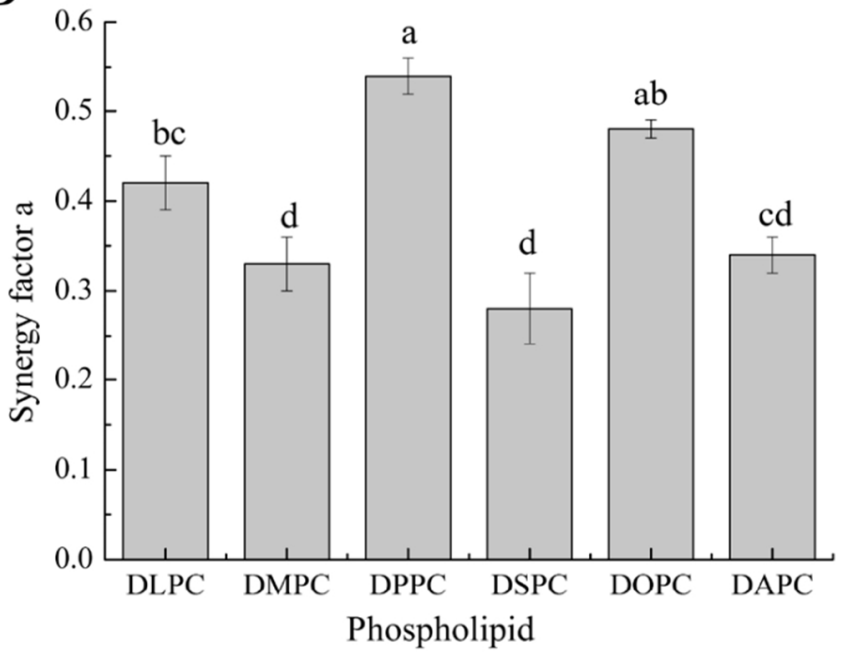

Figure 2 
A

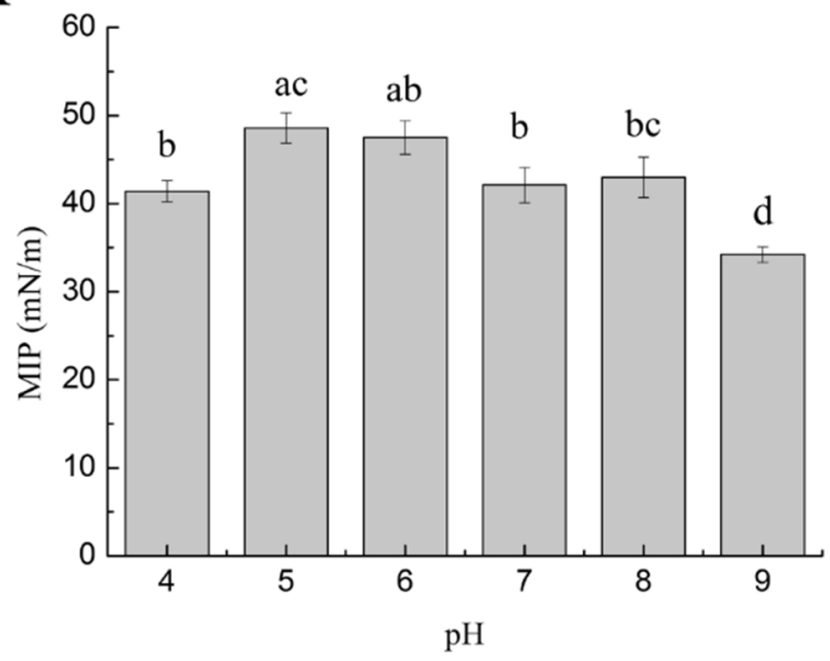

B

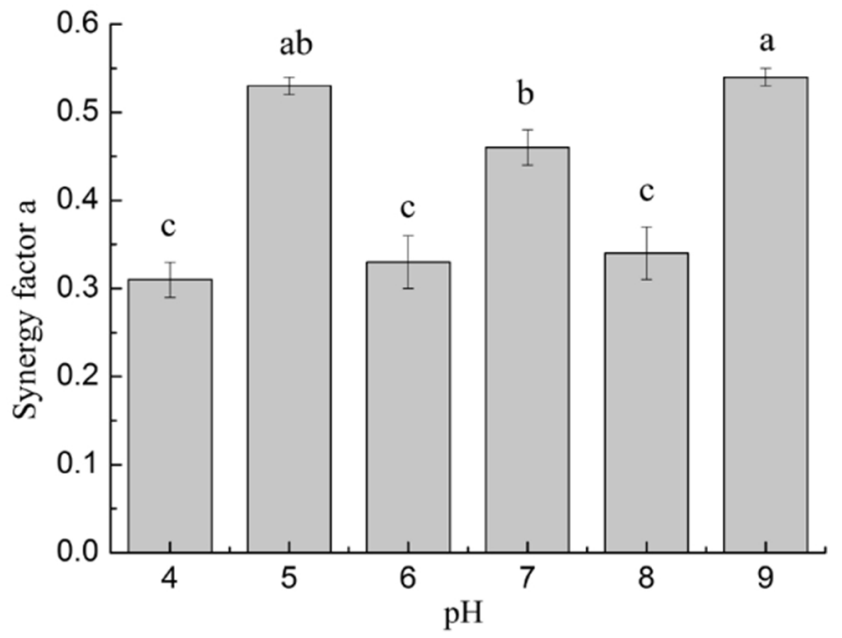

Figure 3 


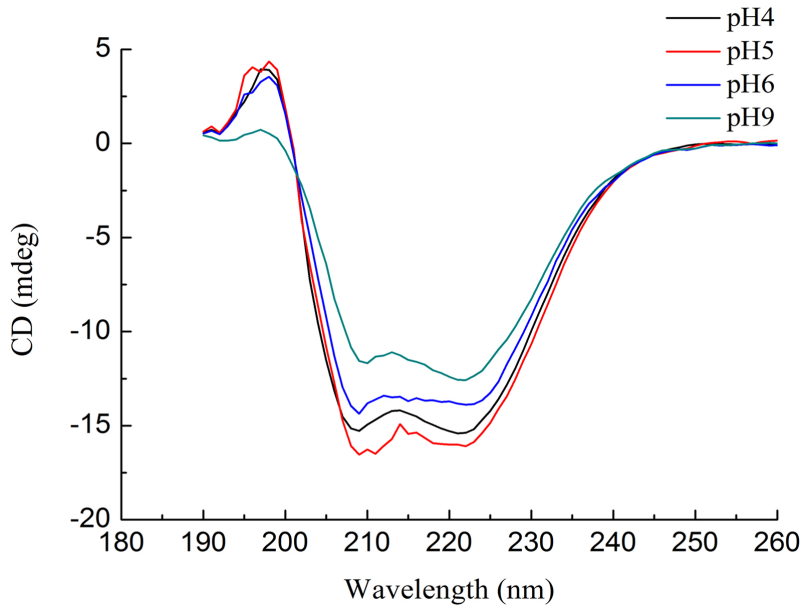

Figure 4 
A

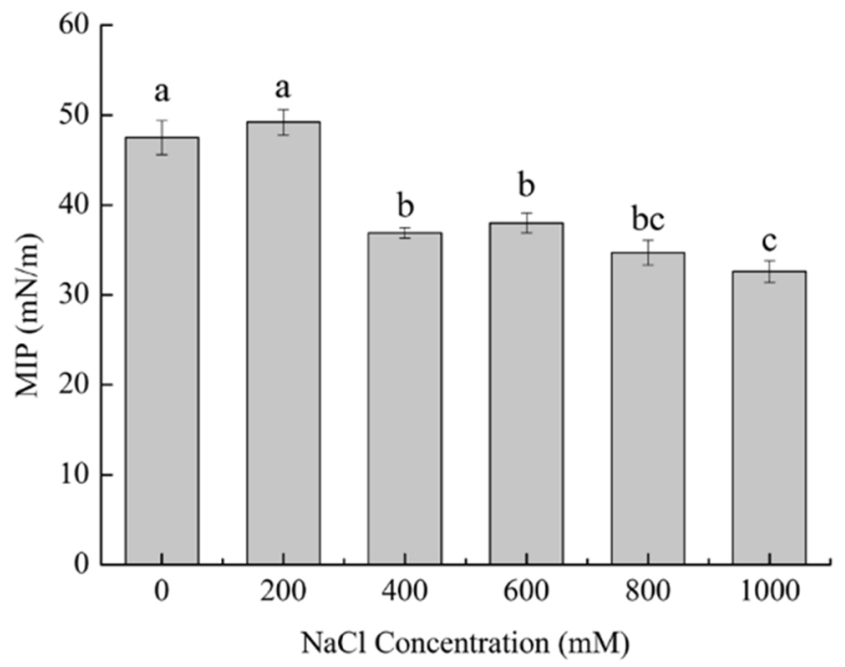

B

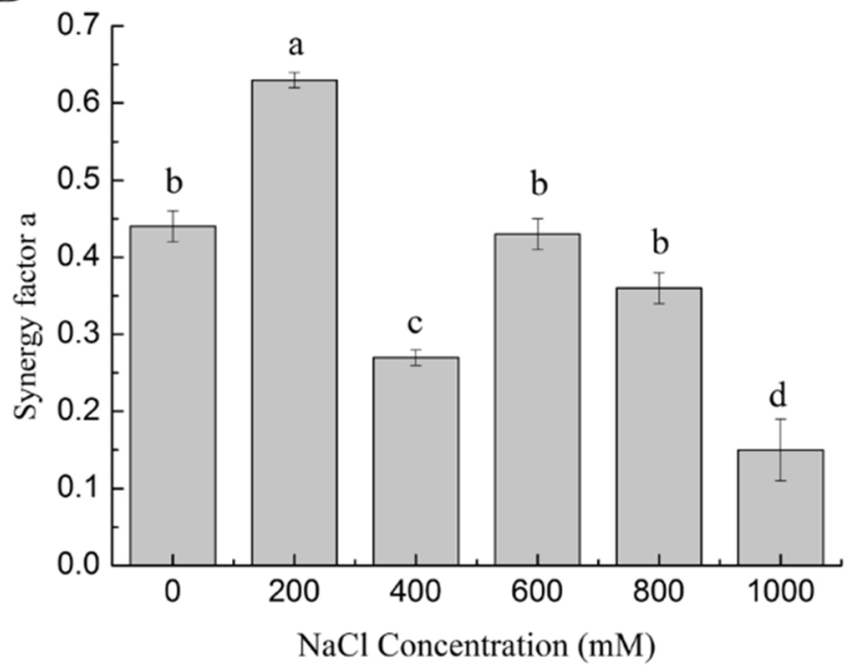

Figure 5 